\title{
Negative Earnings In International Equity Valuation
}

Kathy H. Y. Hsu, University of Louisiana at Lafayette, USA

Harlan L. Etheridge, University of Louisiana at Lafayette, USA

\begin{abstract}
The openness of international capital markets has encouraged investors to look beyond their own national boundary for investment opportunities. Foreign direct investment flow has increased in recent years around the world in all major and emerging markets. International equity valuation, as a result, has gained much attention from practitioners and academic researchers alike. Motivated by evidence that the price-earnings relation is not homogeneous across profit and loss firms and by the growing body of international accounting literature that documents and compares the value relevance of earnings and book value across national boundaries, this study illustrates the potential impact of negative earnings (loss firms) on comparing the relative value relevance of earnings and book value across national boundaries. Our results show that removal of negative earnings observations (1) changes the total value relevance of earnings and book value combined (2) changes the relative value relevance of earnings and book value within each country in our study, and (3) changes the relative incremental value relevance of earnings (book value) between the two countries in the study.
\end{abstract}

Keywords: value relevance, earnings, book value, negative earnings

\section{INTRODUCTION}

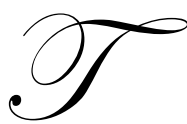

he openness of international capital markets has encouraged investors to look beyond their national boundaries for investment opportunities. In recent years, foreign direct investment flow has increased around the world in all major and emerging markets. International equity valuation, as a result, has attracted much attention from both practitioners and academic researchers.

Extent accounting literature in the area of international equity valuation mainly focuses on the valuation relevance of accounting fundamentals, i.e., accounting earnings and book value. By establishing the valuation relevance of these accounting summary numbers in various countries, researchers have been able to infer the effectiveness of a particular accounting system in capturing information useful for equity valuation. Comparative studies on the overall valuation relevance of accounting summary numbers as well as the relative importance of earnings versus book value in equity valuation across various capital markets also provides a rough indication as to how these accounting fundamentals are used in various capital markets.

The equity valuation models used in this line of accounting research typically assume a positive and homogeneous relation between price and earnings across profits and losses. However, evidence in recent studies by Hayn (1995), Collins, Pincus and Xie (1996) and Caylor, Lopez and Rees (2007) have provided evidence that the price-earnings relation is not homogeneous across profit and loss firms. Nevertheless, the potential impact of this non-homogeneous relation for profit and loss firms is largely ignored in international comparative studies.

Motivated by this caveat and by the growing body of international accounting literature that documents and compares the value relevance of earnings and book value across national boundaries; this study illustrates the potential impact of negative earnings (loss firms) on the relative value relevance of earnings and book value across national boundaries. We propose that in a cross-country comparative study, loss firms need to be separated examined and controlled. Depending on the specific relation between earnings and price for the loss firms of a 
particular country, the inclusion of loss firms in a cross-country comparative study in the overall sample may produce biased results and lead to incorrect beliefs regarding the relative valuation implications of accounting fundamentals across countries.

To illustrate the impact of loss firms, we use a matched sample of U.S. firms listed on the New York Stock Exchange and Canadian firms listed on the Toronto Stock Exchange and investigate if the ranks (first and second) of (1) the combined value relevance of earnings and book value, (2) the relative value relevance of earnings and book value and (3) the relative incremental value relevance of earnings (book value), of the two countries is impacted by the presence of negative earnings firm observations. Our results show that removal of negative earnings observations (1) changes the total value relevance of earnings and book value combined of both countries (2) changes the relative value relevance of earnings and book value within each country, and (3) changes the relative incremental value relevance of earnings (book value) between the two countries. These results not only indicate that separately controlling for loss firms in cross-country comparative studies is an important methodological issue, but also sheds light on the variations in how capital markets across different countries utilize accounting information for valuation purposes.

The remainder of the paper is organized as follows. The next section presents prior research related to the value relevance of earnings and book value and the impact of negative earnings on the value relevance of accounting information and details our hypotheses. A section that details our empirical model follows and leads to a discussion of the data and samples used in our study. The results of our study are discussed next, and the paper ends with a discussion of our conclusions.

\section{PRIOR LITERATURE AND HYPOTHESIS DEVELOPMENT}

Many studies have examined the overall valuation relevance of accounting summary numbers and have compared the relative roles of earnings and book value in equity valuation in various countries. Examples of this line of research include Joos and Lang (1994), which relate book value and earnings to stock prices in France, Germany and the United Kingdom. They find that the combined explanatory power of earnings and book value ranges from $20 \%$ to $38 \%$ for Germany, $48 \%$ to $78 \%$ for France and $14 \%$ to $42 \%$ for the U.K. Harris, Lang and Moller (1994) use a matched sample of U.S. and German firms and find little difference in the overall value relevance $\left(\mathrm{R}^{2}\right)$ of earnings and book value between these two countries. In this same study, the authors also report that the explanatory power of earnings-per-share in Germany is approximately equal to that in the U.S. but find that the explanatory power of book value is much lower in Germany than in the U.S.

King and Langli (1999), which report the effect of accounting diversities on the value relevance of accounting earnings and book value across Germany, Norway and the U.K., find that while book value and earnings are both value relevant in all three countries, German accounting numbers have the lowest correlation with stock prices followed by Norwegian accounting numbers. U.K. accounting numbers have the highest relation with stock prices. Furthermore, they also find that the incremental and relative explanatory power of book value and that of earnings differ across time and across the three countries. The relative explanatory power of book value is greater than that of earnings in German and Norway, but the opposite is true in the U.K. Earnings have little incremental explanatory power in Norway and the explanatory power common to book value earnings is high in U.K. and in Norway but is almost zero in Germany.

Most of these studies use the Edward-Bell-Ohlson valuation model (Bernard, 1994) to examine the value relevance of earnings and book value in relation to equity value. This model shows that stock price is the sum of the book value of equity and the present value of future abnormal earnings. Based on this valuation framework, the value relevance of book value lies in (1) its role as a proxy for the present value of expected future normal earnings, and (2) its ability to reflect a firm's adaptation (Burgstahler and Dichev, 1997) or abandonment value (Berger et al., 1996). In other words, when a firm reports a loss (negative earnings), book value should be more value relevant than earnings since it not only serves as a better proxy than earnings for expected future normal earnings for loss firms, but also serves as a proxy for the adaptation option for loss firms that are likely to seek liquidation, and a proxy for the abandonment option for firms that decide to cease operations. However, none of these international 
accounting studies consider the potential effects that negative earnings may have on the comparative results or the conclusions drawn.

U.S. empirical evidence thus far suggests that there has been a decline in the value-relevance of accounting earnings accompanied by an increase in the value-relevance of accounting book value over the past several decades (Lev, 1997; Collins et al., 1997). Evidence also points to several factors that may explain this shift in value relevance including an increase in frequency and magnitude of one-time items on the income statement, negative earnings, and changes in average firm size and intangible intensity across time (Collins et al., 1997). These results seem to suggest that book value has a substitution effect in firm valuation when earnings becomes a weak proxy for firm value due to losses or the existence of transitory components.

In a related line of research, Hayn (1995) reports that that the cross-sectional return-earnings relation for loss firms is much weaker than that for profit firms. Jan and Ou (1995) and Burgstahler and Dichev (1995) both document that the firms with greater negative earnings per share tend to sell at a higher price than firms with lower negative earnings per share. Collins et al (1997) report that for U.S. firms, book value is more value relevant than earnings when losses are reported. They also document that when the effect of negative earnings observations are removed from the sample (profit-firm observations only), the relative explanatory power of earnings increases and the relative explanatory power of book value decreases. Thus, the inclusion of loss firms in the sample of a study comparing the relative value relevance of earnings and book value across countries can affect the observed relative value relevance of earnings and book value across countries and the related conclusions.

Based on this prior evidence, we hypothesize that, depending on the magnitude of the negative earnings effect, the inclusion of loss-firm observations in a sample can potentially (1) decrease the overall observed value relevance level of earnings and book value combined, and (2) decrease the relative value relevance of accounting earnings or increase the relative value relevance of book value. In the context of international equity valuation, we also believe that conclusions and comparative results can be misleading when loss firms affect the value relevance of earnings and book value to varying degrees across different countries.

\section{EMPIRICAL MODEL}

To illustrate the impact of loss firms on the overall and the relative valuation relevance of earnings and book value, three contemporaneous relations between market value-measures and accounting information are examined for the overall sample, profit-firm sample and loss-firm sample: (1) the earnings relation - the ability of earnings to explain market values; (2) the balance sheet relation - the ability of accounting book value to explain market values; and (3) the combined relation - the ability of earnings and book value jointly to explain market values. Three empirical models are developed to examine these relations:

Earnings model: $P_{i t}=\alpha^{\prime} 0 t+\alpha^{\prime}{ }_{1 t} E_{i t}+v^{\prime}$ it

Book value model: $P_{i t}=\alpha^{\prime \prime}{ }_{0 t}++\alpha{ }_{2 t} B V_{i t}+v^{\prime \prime}{ }_{i t}$

Combined model: $\mathrm{P}_{\mathrm{it}}=\gamma_{0 \mathrm{t}}+\gamma_{1 \mathrm{t}} \mathrm{E}_{\mathrm{it}}+\gamma_{2 \mathrm{t}} \mathrm{BV} \mathrm{V}_{\mathrm{it}}+\varepsilon_{\mathrm{it}}$

where,

$\mathrm{P}_{\text {it }}$ is the cum-dividend market equity for firm $i$ at time $t$,

$E_{i t}$ is accounting earnings of firm $i$ at time $t$,

$\mathrm{BV}_{\mathrm{it}}$ is the book value of firm $\mathrm{i}$ at the beginning of period $t$, and

$\varepsilon_{\mathrm{it}}$ is the error term ${ }^{1}$.

1 The variables in all three models represent per-share values. 
We use the strength of association (adjusted $\mathrm{R}^{2}$ ) between the accounting fundamentals and market values to infer value relevance. Three measures, $R_{T, E}^{2}$ from equation (1), $R_{T, B V}^{2}$ from equation (2) and $R_{T}^{2}$ from equation (3) denote the value relevance of earnings, the value relevance of book value, and the value relevance of earnings and book value combined, respectfully.

To see if U.S. and Canadian accounting numbers differ in their value relevance, we compare crosssectionally and inter-temporally the $\mathrm{R}_{\mathrm{T}}{ }_{\mathrm{T}}$ of the Canadian combined model and the $\mathrm{R}_{\mathrm{T}}{ }_{\mathrm{T}}$ of the U.S. combined model. To investigate the differential valuation implication of Canadian and U.S. earnings and book value, we utilize the incremental value relevance measure that is used in Collins et al., (1997) and Easton (1985), and is derived theoretically by Theil (1971). The measure includes three parts: $\mathrm{R}_{\mathrm{T}}^{2}-\mathrm{R}_{\mathrm{T}, \mathrm{E}}^{2}=\mathrm{IBV}$, where IBV represents the incremental value relevance of accounting book value (value relevant information that is uniquely contained in accounting book value); $\mathrm{R}_{\mathrm{T}}^{2}-\mathrm{R}_{\mathrm{T}, \mathrm{BV}}^{2}=\mathrm{IE}$, where IE represents the incremental value relevance of accounting earnings (value relevant information that is uniquely contained in earnings), and $\mathrm{R}_{\mathrm{T}}^{2}-\mathrm{IE}-\mathrm{IBV}=\mathrm{COMMON}$, where COMMON is the measure of the explanatory power common to both earnings and book value (value relevant information that is contained jointly in earnings and book value). A significant IE (IBV) would mean that earnings (book value) has incremental explanatory power over and beyond what is contained in combined earnings and book value. If IE is greater than IBV, then accounting earnings is more value relevant than book value, and the converse is true if IBV is greater than IE.

Using these three measures, IE, IBV and COMMON, we investigate whether the rankings of these two countries based on (1) the combined value relevance of earnings and book value, (2) the relative value relevance of earnings and book value and (3) the relative incremental value relevance of earnings (book value), is impacted by the presence (or absence) of loss-firm observations.

\section{DATA AND SAMPLE}

Our sample of both U.S. and Canadian firms is selected from the Global Vantage Industrial/Commercial and Issue Files from the period 1983-1991 using the following criteria: (1) annual earnings, earnings before extraordinary items, book value, and closing security prices 3 months after the fiscal year-end of the firm are all available; (2) the sample is restricted to firms listed on the largest exchange in the U.S. and firms listed on the largest exchange in Canada to increase the homogeneity of the sample, i.e., the New York Stock Exchange (NYSE: U.S.) and the Toronto Stock Exchange (TSE: Canada), since the largest exchanges tend to have the highest market efficiency; (3) the firms do not have negative shareholder's equity ${ }^{2}$; (4) only data prepared according to domestic standards is used, due to the research questions addressed by this study; and (5)the top and bottom one-percent of observations are Winsorized to reduce the potential effect of outliers. A sample firm is considered as belonging to a certain country only if it is both incorporated and listed on the exchange of the same country.

After applying these restrictions, we obtain 4104 U.S. firm-year observations and 2181 Canadian firm-year observations in our initial sample. Table 1 reports the descriptive statistics of this initial sample, and it shows that Canadian firms in the full sample generally have much lower earnings (1.344 vs. 3.052), book value (16.468 vs. 28.041 ), share prices ( 20.928 vs. 47.203 ) and size ( 0.437 vs. 1.408 , as measured by market value) than those of the U.S. firms. However, the variability (standard deviation) of these variables is much lower for the Canadian firms compared to the U.S. firms.

\footnotetext{
2 Sixty observations with negative book values are deleted from our sample of firms from each country.
} 
Table 1

Descriptive Statistics

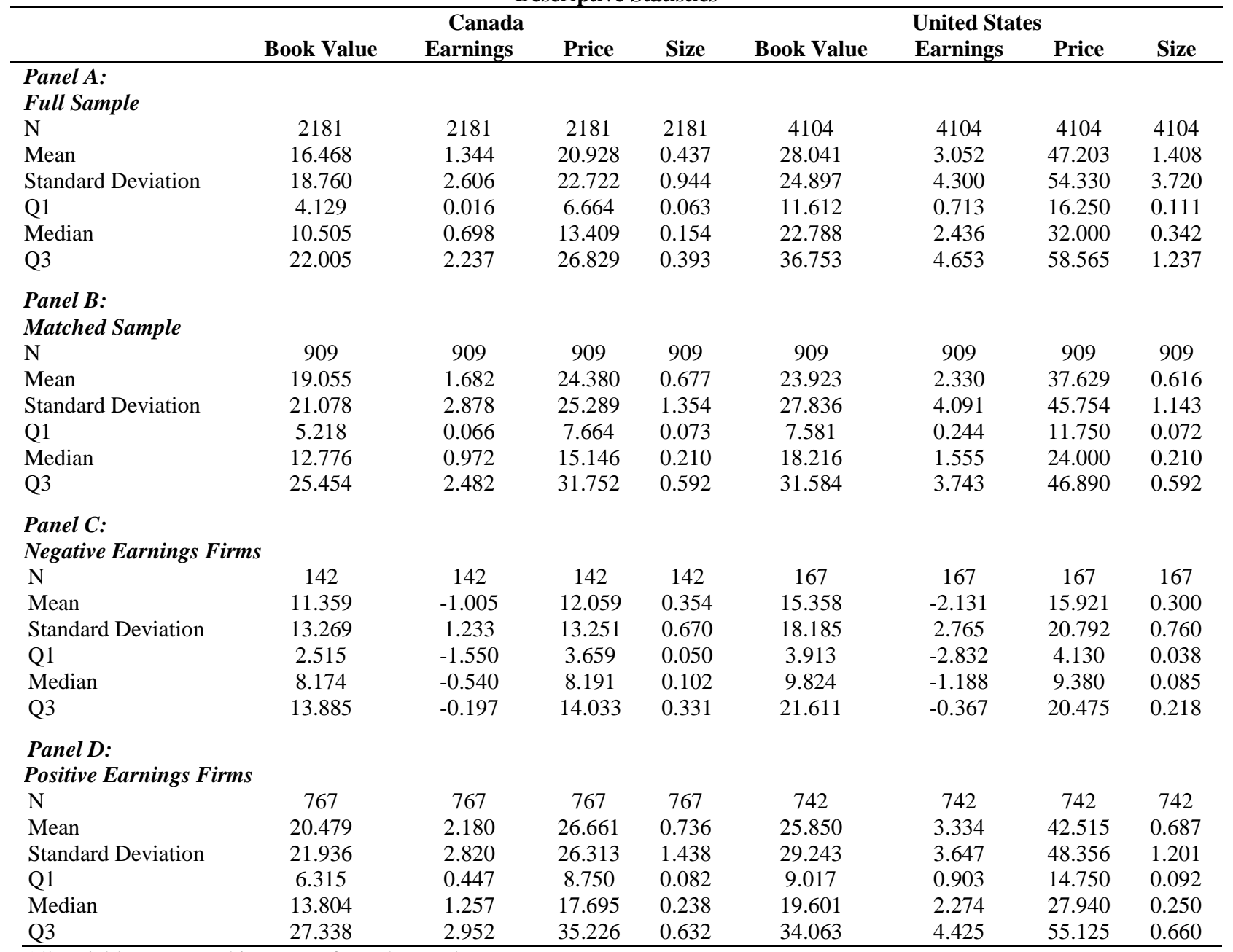

All variables are stated in terms of per share values.

Additionally, as reported in the Appendix A., there also is a difference in the industry composition of the NYSE firms and the TSE firms. The industry composition of our initial Canadian sample consists mainly of extractive industries (592 observations), telecommunication firms (150 observations), paper product firms (117) and steel companies (104). The industry composition of the initial NYSE is more diversified, and the largest number of observations in our U.S. sample comes from the utility industry (623), machinery (318), electronics (240) and chemicals (229). Since most of our research questions involve comparisons across the two countries, we match our sample observations of the two countries by industry 3 and by size (market value) to control for these differences. After matching by industry and size, our final sample contains 909 firm-year observations from each country. Canadian firms in the matched sample consist of 767 profit firms (firms reporting positive earnings) and 142 loss firms (firms reporting negative earnings) while the matched sample contains 742 U.S. profit firms and 167 U.S. loss firms. Our empirical tests are conducted using this matched sample set ${ }^{4}$.

3 Canadian and U.S. sample firms are matched yearly based on two-digit SIC codes and then by firm size, which is measured by market value.

${ }^{4}$ For a complete list of industries that are included in our restricted sample, see Appendix B. Since the matching criteria require the elimination of observations within certain industries and of certain sizes, our results may not be generalizable and should be interpreted with caution. 
In order to analyze the impact of negative earnings on the relative value relevance of earnings and book value of the two countries, we divide the matched sample into loss firms and profit firms. Panels C and D of Table 1 indicate that loss firms of both countries are smaller than profit firms in terms of book value (Canada 11.359 vs. 20.479; U.S. 15.358 vs. 25.850), share prices (Canada 12.059 vs. 26.661; U.S. 15.921 vs. 42.515 ), and size (Canada 0.354 vs. 0.736; U.S. 0.300 vs. 0.687). U.S. loss firms, on average, have larger book value (15.358) than Canadian loss firms (11.359) and have smaller average market capitalization (0.300) than Canadian loss firms (0.354); however, U.S. loss firms have larger average negative earnings (-2.131 vs. -1.005$)$ and share prices (15.921 vs. 12.059) than their Canadian counterparts. Canadian profit firms, on average, are larger in terms of market value (0.736) than U.S. profit firms (0.687). Canadian profit firms also have, on average, smaller book value (20.479 vs. 25.850 ), earnings ( 2.180 vs. 3.334$)$, and share prices (26.661 vs. 42.515$)$ than U.S. profit firms.

Table 2 reports the correlation analysis of our regression variables: price, earnings, and book value. As expected, earnings and book value are positively correlated with price and with each other. The correlation between book value and price is stronger for Canadian loss firms (0.844) than that for Canadian profit firms (0.720), while the correlation between earnings and price is stronger for Canadian profit firms $(0.676)$ than that for Canadian loss firms (-0.451). However, the correlations between earnings and price and book value and price are stronger for U.S. profit firms $(0.814,0.759)$ than those for U.S. loss firms $(-0.363,0.444)$. Note, however, that for U.S. profit firms, earnings has a stronger correlation with price (0.814) than does book value (0.759), but that for U.S. loss firms, book value has a stronger correlation with price $(0.444)$ than does earnings $(-0.363)$.

Table 2

Correlation Analysis

\begin{tabular}{|c|c|c|c|c|c|c|c|c|}
\hline & \multicolumn{4}{|c|}{ Canada } & \multicolumn{4}{|c|}{ United States } \\
\hline & Price & Earnings & B.V. & Size & Price & Earnings & B.V. & Size \\
\hline \multicolumn{9}{|c|}{$\begin{array}{l}\text { Panel A: } \\
\text { Full Sample }\end{array}$} \\
\hline Price & 1.000 & 0.620 & 0.739 & 0.347 & 1.000 & 0.749 & 0.683 & 0.340 \\
\hline Earnings & 0.620 & 1.000 & 0.691 & 0.153 & 0.749 & 1.000 & 0.634 & 0.298 \\
\hline B.V. & 0.739 & 0.691 & 1.000 & 0.189 & 0.683 & 0.634 & 1.000 & 0.263 \\
\hline Size & 0.347 & 0.153 & 0.189 & 1.000 & 0.340 & 0.298 & 0.263 & 1.000 \\
\hline \multicolumn{9}{|l|}{ Panel B: } \\
\hline \multicolumn{9}{|c|}{ Matched Sample } \\
\hline Price & 1.000 & 0.650 & 0.734 & 0.325 & 1.000 & 0.722 & 0.744 & 0.263 \\
\hline Earnings & 0.650 & 1.000 & 0.805 & 0.128 & 0.722 & 1.000 & 0.572 & 0.206 \\
\hline B.V. & 0.734 & 0.805 & 1.000 & 0.162 & 0.744 & 0.572 & 1.000 & 0.205 \\
\hline Size & 0.325 & 0.128 & 0.162 & 1.000 & 0.263 & 0.206 & 0.205 & 1.000 \\
\hline \multicolumn{9}{|l|}{ Panel C: } \\
\hline \multicolumn{9}{|c|}{ Negative Earnings Firms } \\
\hline Price & 1.000 & -0.451 & 0.844 & 0.421 & 1.000 & -0.363 & 0.444 & 0.344 \\
\hline Earnings & -0.451 & 1.000 & -0.469 & -0.388 & -0.363 & 1.000 & -0.458 & -0.121 \\
\hline B.V. & 0.844 & -0.469 & 1.000 & 0.356 & 0.444 & -0.458 & 1.000 & 0.173 \\
\hline Size & 0.421 & -0.388 & 0.356 & 1.000 & 0.344 & -0.121 & 0.173 & 1.000 \\
\hline \multicolumn{9}{|l|}{ Panel D: } \\
\hline \multicolumn{9}{|c|}{ Positive Earnings Firms } \\
\hline Price & 1.000 & 0.676 & 0.720 & 0.308 & 1.000 & 0.814 & 0.759 & 0.236 \\
\hline Earnings & 0.676 & 1.000 & 0.885 & 0.113 & 0.814 & 1.000 & 0.698 & 0.194 \\
\hline B.V. & 0.720 & 0.885 & 1.000 & 0.138 & 0.759 & 0.698 & 1.000 & 0.191 \\
\hline Size & 0.308 & 0.113 & 0.138 & 1.000 & 0.236 & 0.194 & 0.191 & 1.000 \\
\hline
\end{tabular}

All values reported are Pearson Correlation Coefficients.

This evidence, by itself, seems to indicate that the Canadian market places a stronger emphasis on book value than earnings when valuing both profit and loss firms. Earnings seem to have a stronger role in the valuation 
of Canadian profit firms than in the valuation of Canadian loss firms. The U.S. market seems to use earnings to a greater extent than book value when valuing profit firms; the opposite is true for loss firms. However, when valuing loss firms, the U.S. market does not seem to use either book value or earnings to the extent that the Canadian market does $^{5}$.

\section{REGRESSION RESULTS}

\section{Value Relevance Of Earnings And Book Value Combined Overall Sample}

Table 3 shows the result of our regression analysis for the complete matched sample without separating out the loss firms from the profit firms. This result serves as a baseline for our subsequent comparisons with the results of the profit-firms-only sample and those of the loss-firms-only sample. As evidenced in Table 3, earnings and book value together explain a significant portion of equity value in both countries (the adjusted $R^{2}$ is 0.56 for Canada and 0.647 for the U.S.). However, while $\mathrm{R}_{\mathrm{T}, \mathrm{US}}^{2}$ is consistently greater than $\mathrm{R}_{\mathrm{T}, \mathrm{CA}}^{2}$ in each of the three sample periods, the variable DIFF $^{6}$-- which measures the extent of the difference between the value relevance of Canadian earnings and book value combined and that of the U.S. $\left(\mathrm{R}_{\mathrm{T}, \mathrm{CA}}^{2}-\mathrm{R}_{\mathrm{T}, \mathrm{US}}^{2}\right)$ shows a consistent decline (-0.257, 0.054 and -0.026 ) over our three sample time periods (also see Figure 1).

Table 3

Value Relevance of Earnings and Book Value Combined

$$
\text { Model: } P_{i t}=\gamma_{0 t}+\gamma_{1 t} E_{i t}+\gamma_{2 t} B V_{i t}+\varepsilon_{i t}
$$

\begin{tabular}{lccccccccc}
\hline \multicolumn{1}{l}{ Period } & $\mathbf{N}$ & $\mathbf{R}_{\mathbf{T}}^{\mathbf{2}}$ & $\mathbf{E}$ & $\mathbf{B V}$ & $\mathbf{N}$ & $\mathbf{R}_{\mathbf{T}}^{\mathbf{2}}$ & $\mathbf{E}$ & $\mathbf{B V}$ & \multicolumn{2}{c}{ DIFF } \\
\hline $1983-1985$ & 257 & 0.320 & 0.913 & 0.380 & 257 & 0.576 & 3.327 & 0.543 & -0.257 \\
$1986-1988$ & 341 & 0.586 & 2.818 & 0.591 & 341 & 0.640 & 5.160 & 0.677 & -0.054 \\
$1989-1991$ & 311 & 0.699 & 1.831 & 0.953 & 311 & 0.725 & 5.591 & 0.834 & -0.026 \\
Pooled & 909 & 0.548 & 1.479 & 0.718 & 909 & 0.684 & 4.921 & 0.810 & -0.136 \\
Mean Analysis & 9 & 0.560 & 2.202 & 0.637 & 9 & 0.647 & 4.837 & 0.704 & -0.087 \\
& & $(10.134)$ & $(5.256)$ & $(6.477)$ & & $(14.850)$ & $(9.866)$ & $(10.652)$ & $(-1.668)$ \\
& & {$[0.000]$} & {$[0.001]$} & {$[0.000]$} & & {$[0.000]$} & {$[0.000]$} & {$[0.000]$} & {$[0.134]$} \\
\hline
\end{tabular}

Notes: Coefficient estimates are based on ordinary least-squares estimation. The table reports the coefficient estimates, $\mathrm{t}-$ statistics, and p-values from cross-sectional and inter-temporal regressions. T-statistics are shown in parentheses and p-values are in brackets.

$\mathrm{R}_{\mathrm{T}}^{2}$ is the measure of the value-relevance of combined earnings and book value. $\mathrm{E}$ is the coefficient of earnings. BV is the coefficient of book value. DIFF is the difference between the Canadian combined value-relevance measure, $\mathrm{R}_{\mathrm{T}}^{2}$, and the U.S. $\mathrm{R}_{\mathrm{T}}^{2}$.

The sample consists of U.S. and Canadian firm-year observations matched by both industry and size.

\footnotetext{
5 Page: 15We do not test the differences in correlations reported in Table 2 for statistical significance. We use regression models to analyze the relationships between price and earnings and book value and test these relationships for statistical significance. The results of these tests are reported in Tables $3-6$.

6 DIFF is measure of the difference between the U.S. $\mathrm{R}_{\mathrm{T}}^{2}$ of the combined model and the Canadian $\mathrm{R}_{\mathrm{T}}^{2}$. A negative number in DIFF indicates that the U.S. total value relevance of earnings and book value is greater than that of the Canadian accounting numbers.
} 
Figure 1

Value Relevance of Earnings and Book Value Combined

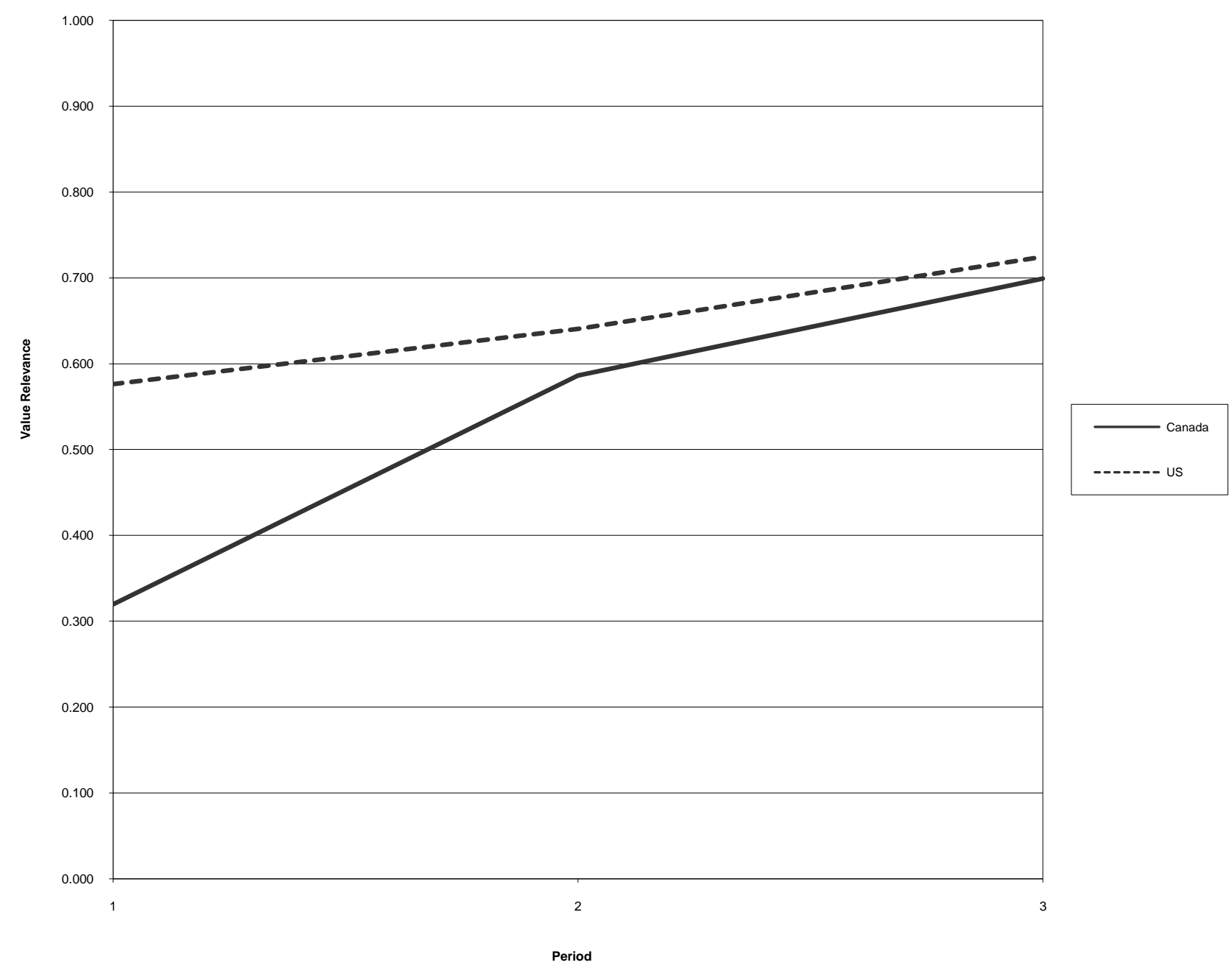

The results reported in Table 3 indicate that the extent of the difference between the value relevance of accounting numbers of these two countries has decreased, while the combined value relevance of accounting summary numbers of each country has increased. This is because the value relevance of Canadian earnings and book value has increased at a relatively faster pace than that of U.S. earnings and book value. This evidence suggests that the GAAP differences that cause the valuation differences of earnings and the book value across the two countries are gradually being reduced over time. Due to this harmonization trend, the mean analysis of the DIFF variable is insignificant. Without further information on the effect of loss firms, this evidence leads us to conclude that while differences do exist between the value relevance of combined Canadian earnings and book value and that of combined U.S. earnings and book value, on average, they are insignificant. This conclusion seems to corroborate the findings of prior studies and the common perception that the accounting earnings and book values produced under these two GAAP systems do have similar market valuation implications. 


\section{Profit Versus Loss Firms}

Table 4 reports the results of the comparison of the overall value relevance of the two countries after separating the loss firms from the profit firms. As reported in Table 1, panel C, the U.S. loss firms subgroup has more observations (167) a larger mean book value (15.358) and lower mean earnings (-2.131) than the Canadian loss firms subgroup $(142,11.359,-1.005)$. However, the U.S. and Canadian loss firm observations are comparable in size ( 0.300 for the U.S. and 0.354 for Canada). By separately comparing the combined value relevance of earnings and book value of the loss firms and that of the profit firms, a different picture of the relative ranking of the accounting summary numbers of these two GAAP systems emerges.

Table 4

Value Relevance of Earnings and Book Value Combined -- Profit Firms and Loss Firms

$$
\text { Model: } \mathrm{P}_{\text {it }}=\gamma_{0 \mathrm{t}}+\gamma_{1 \mathrm{t}} \mathrm{E}_{\text {it }}+\gamma_{2 \mathrm{t}} \mathrm{BV}_{\mathrm{it}}+\varepsilon_{\text {it }}
$$

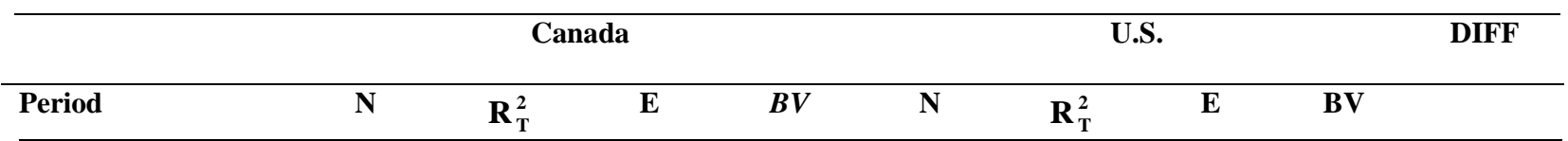

\section{Panel A: Profit Firms}

\begin{tabular}{|c|c|c|c|c|c|c|c|c|c|}
\hline 1983-1985 & 219 & 0.298 & 1.719 & 0.246 & 212 & 0.569 & 5.119 & 0.314 & -0.271 \\
\hline 1986-1988 & 310 & 0.564 & 2.797 & 0.578 & 278 & 0.716 & 9.716 & 0.047 & -0.152 \\
\hline $1989-1991$ & 238 & 0.683 & 1.967 & 0.934 & 252 & 0.781 & 8.052 & 0.684 & -0.098 \\
\hline Pooled & 767 & 0.524 & 1.669 & 0.674 & 742 & 0.732 & 7.345 & 0.615 & -0.208 \\
\hline Mean Analysis & 9 & $\begin{array}{l}0.550 \\
(9.808) \\
{[0.000]}\end{array}$ & $\begin{array}{l}2.236 \\
(3.637) \\
{[0.007]}\end{array}$ & $\begin{array}{l}0.628 \\
(4.995) \\
{[0.001]}\end{array}$ & 9 & $\begin{array}{l}0.724 \\
(19.558) \\
{[0.000]}\end{array}$ & $\begin{array}{l}8.943 \\
(7.367) \\
{[0.000]}\end{array}$ & $\begin{array}{l}0.242 \\
(1.776) \\
{[0.114]}\end{array}$ & $\begin{array}{l}-0.174 \\
(-4.864) \\
{[0.001]}\end{array}$ \\
\hline
\end{tabular}

Panel B: Loss Firms

\begin{tabular}{|c|c|c|c|c|c|c|c|c|c|}
\hline 1983-1985 & 38 & 0.677 & -0.688 & 0.922 & 45 & 0.197 & 0.573 & 0.402 & 0.480 \\
\hline 1986-1988 & 31 & 0.875 & -0.274 & 0.724 & 63 & 0.312 & -0.481 & 1.269 & 0.563 \\
\hline 1989-1991 & 73 & 0.684 & -0.946 & 0.773 & 59 & 0.326 & -2.453 & 0.280 & 0.358 \\
\hline Pooled & 142 & 0.711 & -0.757 & 0.809 & 167 & 0.220 & -1.521 & 0.401 & 0.492 \\
\hline Mean Analysis & 9 & $\begin{array}{l}0.686 \\
(9.516) \\
{[0.000]}\end{array}$ & $\begin{array}{l}-0.603 \\
(-1.320) \\
{[0.223]}\end{array}$ & $\begin{array}{l}0.768 \\
(7.668) \\
{[0.000]}\end{array}$ & 9 & $\begin{array}{l}0.364 \\
(7.578) \\
{[0.000]}\end{array}$ & $\begin{array}{l}-0.262 \\
(-0.331) \\
{[0.749]}\end{array}$ & $\begin{array}{l}0.811 \\
(6.198) \\
{[0.000]}\end{array}$ & $\begin{array}{l}0.322 \\
(3.440) \\
{[0.009]}\end{array}$ \\
\hline
\end{tabular}

Notes: Coefficient estimates are based on ordinary least-squares estimation. The table reports the coefficient estimates, $\mathrm{t}$ statistics, and p-values from cross-sectional regressions. T-statistics are shown in parentheses and p-values are in brackets.

$\mathrm{R}_{\mathrm{T}}^{2}$ is the measure of value-relevance of combined earnings and book value. $\mathrm{E}$ is the coefficient of earnings. BV is the coefficient of book value. DIFF is the difference between the Canadian combined value-relevance measure, $R_{T}^{2}$, and the U.S. $\mathrm{R}_{\mathrm{T}}^{2}$.

Negative and positive earnings subgroups are from the matched sample. The matched sample consists of U.S. and Canadian firm-year observations matched by both industry and size. 
Figure 2

Value Relevance of Earnings and Book Value Combined -- Profit Firms

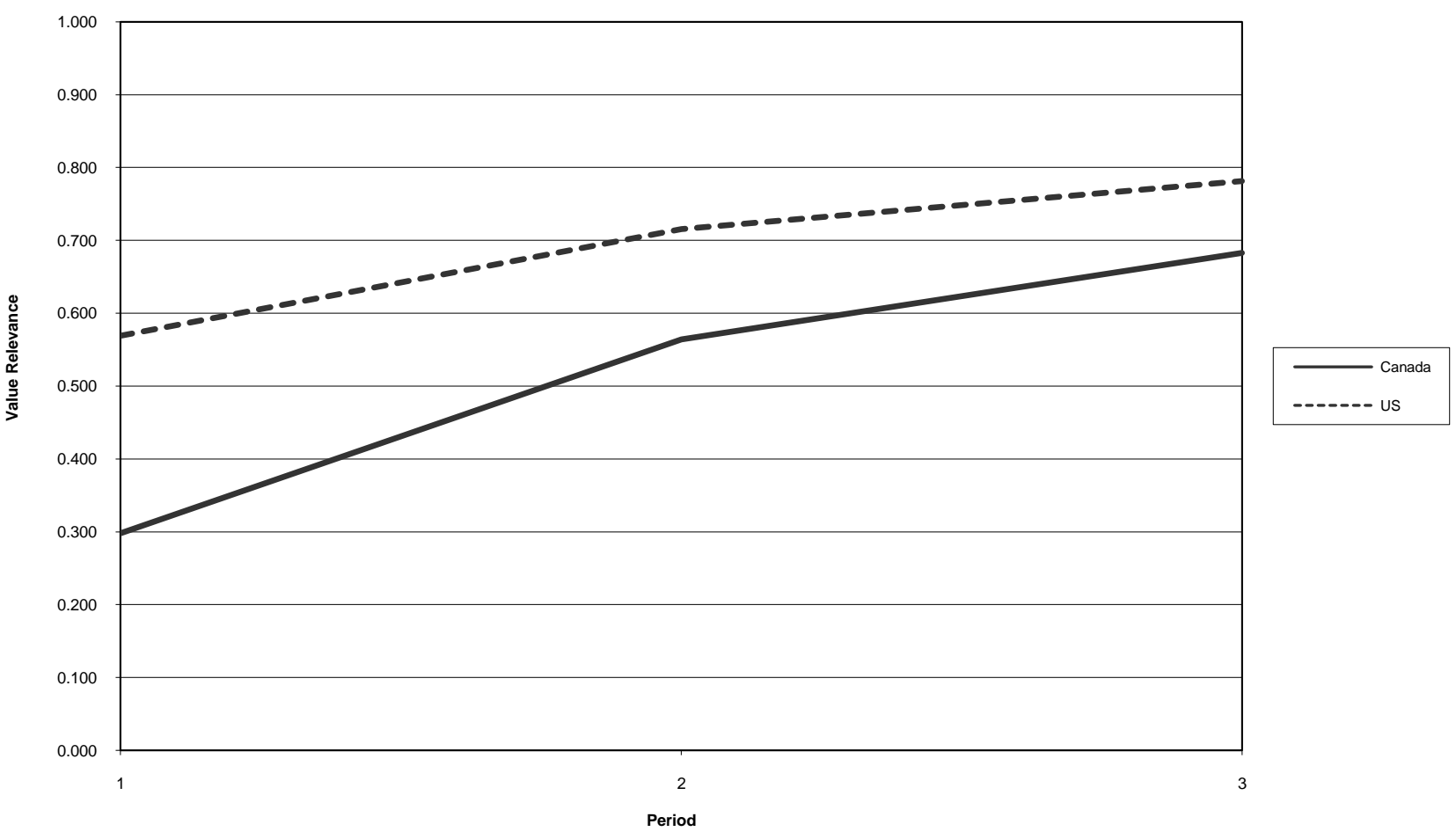

Figure 3

Value Relevance of Earnings and Book Value Combined--Loss Firms

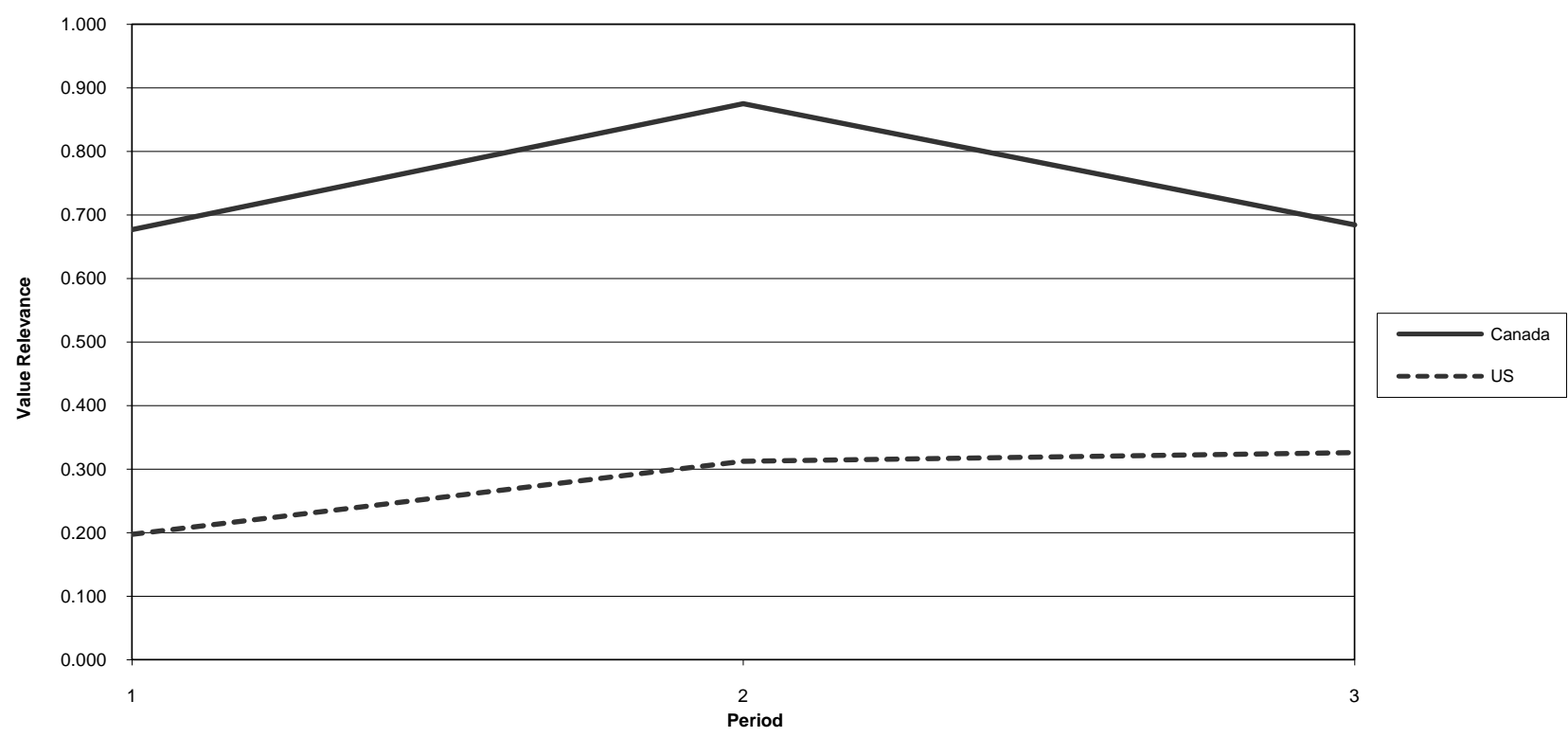


For profit firms, as shown in Figure 2 and in Panel A of Table 4, combined U.S. earnings and book value is significantly more value relevant than combined Canadian earnings and book value in all three sample-periods and in the mean analysis (DIFF=-0.174, p=0.001). Figure 3 and Table 4, Panel B also show that, for loss firms, combined Canadian earnings and book value has much higher value relevance (0.686) than combined U.S. earnings and book value (0.364). This clearly indicates that combined Canadian earnings and book value has valuation implications for loss firms and profit firms that differ from those of combined U.S. earnings and book value. Additionally, this evidence indicates that our previous conclusion (reported in Table 3) that combined Canadian earnings and book value is, on average, value relevant at a level similar to combined U.S. earnings and book value (DIFF $=-0.087, \mathrm{p}=0.134)$ is correct only when loss firms are included in the sample.

Comparing the regression results of the profit-firm sample with those of the loss-firm sample and those of the baseline overall sample generates results that are consistent with prior evidence (Collins et al, 1997) of a higher value relevance for combined U.S. earnings and book value of profit firms than that of U.S. loss firms and that of U.S. mixed samples. Table 4 shows that the value relevance of combined earnings and book value for the U.S. profit firms is significantly greater, both at the average level $(0.724)$ and for each sample period $(0.569,0.716$, and 0.781), than the value relevance of combined earnings and book value for the U.S. mixed sample reported in Table 3 $(0.647,0.576,0.640$ and 0.725 for the pooled sample and each period, respectively) and that of the U.S. loss firms (Table 4 panel B reports an explanatory power of $0.220,0.197,0.312$ and 0.326 for the pooled sample and each period, respectively).

On the other hand, our Canadian results are inconsistent with prior U.S. findings in that the combined value relevance of earnings and book value for Canadian profit firms (0.550) remains at a level similar to that of the mixed sample (0.560). In other words, unlike their U.S. counterparts, removal of negative earnings observations seems to have little impact on the value relevance of combined Canadian earnings and book value. In fact, Table 4 reports a higher value relevance of combined earnings and book value for Canadian loss firms (0.686) than the value relevance of combined earnings and book value for Canadian profit firms $(0.550)$. The results in Table 4 also indicate that combined Canadian earnings and book value, on average, has the ability to explain over $68 \%$ of the variation in security prices for loss firms compared to $36 \%$ for combined U.S. earnings and book value.

Given these results, we conclude that while the inclusion of loss firms does affect the combined value relevance of accounting earnings and book value, the effect varies across countries. For the U.S.-firm sample, inclusion of loss firms substantially decreases the value relevance of earnings and book value combined; however, for the Canadian-firm sample, the removal of loss firms does not improve the value relevance of earnings and book value combined. While our first hypothesis that the value relevance of earnings and book value combined is lower when loss firms are included in the sample is not completely supported by the result; it is evident from the results that loss firms need to be examined separately, especially in the international equity valuation context where comparative analysis across countries is often necessary.

\section{Incremental Value Relevance Of Earnings And Book Value}

Table 5 reports our baseline measure of the relative valuation importance of earnings and book value for the overall sample. Table 5 also reports the incremental value relevance of both earnings and book value for the U.S. and Canada. Canadian book value has significant incremental value relevance over and beyond Canadian earnings (IBV; $\mathrm{p}=0.022$ ). Canadian earnings, on the other hand, show no significant incremental value relevance over and beyond Canadian book value (IE; $p=0.114$ ) and the difference between the incremental value relevance of Canadian earnings and Canadian book value is significant $\left(\operatorname{DIFF}_{\mathrm{CA}}=-0.110 ; \mathrm{p}=0.065\right)$. These results suggest that Canadian equity markets focus more on book value when determining firm value than earnings (book value focus).

Conversely, U.S. earnings and U.S. book value both have incremental explanatory power over and beyond each other (IE $\mathrm{p}=0.000$; IBV $\mathrm{p}=0.001)$, and are comparable in their incremental explanatory power $\left(\mathrm{DIFF}_{\mathrm{US}}=\right.$ 0.022 and is insignificant). These results suggest that while Canadian book value, on average, is more value relevant than Canadian earnings to a significant degree, the U.S. earnings and U.S. book value, on average, are more equivalent in value relevance. 
Table 5

Incremental Value Relevance of Earnings and Book Value

Models:

Earnings model: $P_{\text {it }}=\alpha_{0 \mathrm{t}}+\alpha_{1 \mathrm{t}} \mathrm{E}_{\text {it }}+\varepsilon_{\text {it }}$

Book value model: $P_{\text {it }}=\beta_{0 t}+\beta_{1 \mathrm{t}} \mathrm{BV}_{\text {it }}+\varepsilon_{\text {it }}$

Combined model: $\mathrm{P}_{\text {it }}=\gamma_{0 \mathrm{t}}+\gamma_{1 \mathrm{t}} \mathrm{E}_{\text {it }}+\gamma_{2 \mathrm{t}} \mathrm{BV}_{\text {it }}+\varepsilon_{\text {it }}$

\begin{tabular}{|c|c|c|c|c|c|c|c|c|c|}
\hline & \multicolumn{3}{|c|}{ Canada } & \multicolumn{3}{|c|}{ U.S. } & \multicolumn{3}{|c|}{ Canada vs. U.S. } \\
\hline Period & $\begin{array}{l}\mathbf{A}) \\
\mathbf{I E}^{\mathrm{a}} \\
\end{array}$ & $\begin{array}{c}\text { (B) } \\
\text { IBV }^{\mathbf{b}}\end{array}$ & $\begin{array}{c}(\mathbf{A}-\mathbf{B}) \\
\text { DIFF }_{C A} \\
\end{array}$ & $\begin{array}{l}\text { (C) } \\
\text { IE }\end{array}$ & $\begin{array}{l}\text { (D) } \\
\text { IBV }\end{array}$ & $\begin{array}{c}\text { (C-D) } \\
\text { DIFF }_{\text {US }} \\
\end{array}$ & $\begin{array}{c}\text { (A-C) } \\
\text { DIFF }_{\text {IE }} \\
\end{array}$ & $\begin{array}{c}\text { (B-D) } \\
\text { DIFF }_{\text {IBV }}\end{array}$ & DIFF $_{\text {common }}{ }^{\mathrm{c}}$ \\
\hline 1983-1985 & 0.005 & 0.065 & -0.060 & 0.135 & 0.104 & 0.031 & -0.130 & -0.038 & -0.088 \\
\hline 1986-1988 & 0.018 & 0.042 & -0.025 & 0.095 & 0.049 & 0.047 & -0.077 & -0.006 & 0.030 \\
\hline 1989-1991 & 0.014 & 0.234 & -0.220 & 0.155 & 0.205 & -0.049 & -0.142 & 0.029 & 0.087 \\
\hline Pooled & 0.009 & 0.126 & -0.116 & 0.130 & 0.163 & -0.033 & -0.121 & -0.038 & 0.022 \\
\hline Mean Analysis & $\begin{array}{r}0.020 \\
(1.773) \\
{[0.114]} \\
\end{array}$ & $\begin{array}{c}0.130 \\
(2.847) \\
{[0.022]} \\
\end{array}$ & $\begin{array}{c}-0.110 \\
(-2.139) \\
{[0.065]}\end{array}$ & $\begin{array}{c}0.143 \\
(5.714) \\
{[0.000]}\end{array}$ & $\begin{array}{c}0.121 \\
(4.793) \\
{[0.001]}\end{array}$ & $\begin{array}{c}0.022 \\
(0.676) \\
{[0.518]}\end{array}$ & $\begin{array}{c}-0.123 \\
(-5.440) \\
{[0.001]}\end{array}$ & $\begin{array}{c}0.009 \\
(0.208) \\
{[0.840]}\end{array}$ & $\begin{array}{c}0.027 \\
(0.755) \\
{[0.472]}\end{array}$ \\
\hline
\end{tabular}

Notes: Coefficient estimates are based on ordinary least-squares estimation. The table reports the coefficient estimates, tstatistics, and p-values from cross-sectional regressions. T-statistics are shown in parentheses and p-values are in brackets.

${ }^{a} I E$ is the measure of the incremental value relevance of earnings and is estimated by $R_{T}^{2}-I B V$.

${ }^{b} \mathrm{IBV}$ is the measure of the incremental value relevance of book value and is estimated by $\mathrm{R}_{\mathrm{T}}^{2}$ - IE.

${ }^{\mathrm{c}} \mathrm{DIFF}_{\text {common }}$ is the value relevance common to Canadian earnings and book value over that of U.S. earnings and book value and is calculated as Canadian ( $R_{T}^{2}$ - IE - IBV) - U.S. ( $\mathrm{R}_{\mathrm{T}}^{2}$ - IE - IBV).

Negative and positive earnings subgroups are from the matched sample. The matched sample consists of U.S. and Canadian firm-year observations matched by both industry and size.

To see the impact of loss firms on the results reported in Table 5, we separately test the incremental value relevance of earnings and of book value for profit firms and for loss firms. Table 6, Panel A reports that for Canadian profit firms, book value has incremental explanatory power over and beyond earnings $(p=0.014)$ but the converse is not true for Canadian earnings $(p=0.152)$. This is similar to the results reported in Table 5 for the overall sample. However, while the $\mathrm{DIFF}_{\mathrm{CA}}$ in Table 5 indicates that a significant difference exists between IE and IBV $(-1.110, p=0.065)$ at the mean level, $\mathrm{DIFF}_{\mathrm{CA}}$ for the profit firm sample shows no significant difference between the two variables $\left(\mathrm{DIFF}_{\mathrm{CA}}=-0.025, \mathrm{p}=0.447\right)$. This result is due to the lower value of $\mathrm{IBV}_{\mathrm{CA}}$ after the removal of loss firm observations. It also can be seen that for Canadian loss firms (Table 6, Panel B), book value has significant incremental value relevance over earnings $(\mathrm{p}=0.001)$, but Canadian earnings does not have significant incremental value relevance over Canadian book value $(\mathrm{p}=0.916)$, and the difference between the levels of incremental value relevance $\left(\mathrm{DIFF}_{\mathrm{CA}}\right)$ is significant $(\mathrm{p}=0.001)$.

Earnings is the main valuation variable for U.S. profit firms and has incremental value relevance over and beyond book value $(\mathrm{p}=0.000)$. Accounting book value, on the other hand, does not have incremental explanatory power over earnings when U.S. firms report positive earnings $(\mathrm{p}=0.119)$. Since IBV is no longer significant after the loss firms are removed, this result is different from that reported in Table 5 for the full U.S. sample. For the U.S. loss-firm sample, book value also exhibits significant incremental value relevance over earnings $(p=0.001)$, but earnings do not have incremental value relevance over book value $(\mathrm{p}=0.348)$ and the difference between them also is significant $(\mathrm{p}=0.009)$. 
Table 6

Incremental Value Relevance of Earnings and Book Value - Profit Firms and Loss Firms

$\begin{array}{ll}\text { Models: } & \text { Earnings model: } \mathrm{P}_{\text {it }}=\alpha_{0 \mathrm{t}}+\alpha_{1 \mathrm{t}} \mathrm{E}_{\mathrm{it}}+\varepsilon_{\text {it }} \\ & \text { Book value model: } \mathrm{P}_{\text {it }}=\beta_{0 \mathrm{t}}+\beta_{1 \mathrm{t}} \mathrm{BV}_{\mathrm{it}}+\varepsilon_{\text {it }} \\ & \text { Combined model: } \mathrm{P}_{\mathrm{it}}=\gamma_{\mathrm{Ot}}+\gamma_{1 \mathrm{t}} \mathrm{E}_{\mathrm{it}}+\gamma_{2 \mathrm{t}} \mathrm{BV}_{\mathrm{it}}+\varepsilon_{\mathrm{it}}\end{array}$

\begin{tabular}{|c|c|c|c|c|c|c|c|c|c|}
\hline \multicolumn{3}{|c|}{ Canada } & \multicolumn{3}{|c|}{ U.S. } & \multicolumn{4}{|c|}{ Canada vs. U.S. } \\
\hline Period & $\begin{array}{l}(\mathbf{A}) \\
\mathbf{I E}^{\mathrm{a}} \\
\end{array}$ & $\begin{array}{l}\text { (B) } \\
\text { IBV }^{\mathbf{b}}\end{array}$ & $\begin{array}{l}(A-B) \\
\text { DIFF }_{C A}\end{array}$ & $\begin{array}{l}\text { C) } \\
\text { IE }\end{array}$ & $\begin{array}{l}\text { (D) } \\
\text { IBV }\end{array}$ & $\begin{array}{l}\text { (C-D) } \\
\text { DIFF }_{\text {US }} \\
\end{array}$ & $\begin{array}{l}\text { (A-C) } \\
\text { DIFF }_{\text {IE }}\end{array}$ & $\begin{array}{l}\text { (B-D) } \\
\text { DIFF }_{\text {IBV }} \\
\end{array}$ & $\begin{array}{c}\text { DIFF } \\
\text { common } \\
\text { con }\end{array}$ \\
\hline \multicolumn{10}{|c|}{ Panel A: Positive Earnings } \\
\hline $1983-1985$ & 0.015 & 0.018 & -0.003 & 0.102 & 0.016 & 0.086 & -0.087 & 0.002 & -0.186 \\
\hline $1986-1988$ & 0.012 & 0.031 & -0.018 & 0.184 & -0.001 & 0.185 & -0.172 & 0.031 & -0.011 \\
\hline $1989-1991$ & 0.006 & 0.113 & -0.107 & 0.185 & 0.109 & 0.075 & -0.179 & 0.004 & 0.077 \\
\hline Pooled & 0.006 & 0.068 & -0.061 & 0.157 & 0.071 & 0.086 & -0.151 & -0.003 & -0.054 \\
\hline \multirow{3}{*}{$\begin{array}{l}\text { Mean } \\
\text { Analysis }\end{array}$} & 0.031 & 0.056 & -0.025 & 0.205 & 0.048 & 0.157 & -0.174 & 0.008 & -0.007 \\
\hline & $(1.583)$ & $(3.123)$ & $(-0.800)$ & $(6.185)$ & $(1.744)$ & $(2.937)$ & $(-5.474)$ & $(0.268)$ & $(-0.181)$ \\
\hline & {$[0.152]$} & {$[0.014]$} & {$[0.447]$} & {$[0.000]$} & [0.119] & {$[0.019]$} & {$[0.001]$} & {$[0.796]$} & {$[0.861]$} \\
\hline \multicolumn{10}{|c|}{ Panel B: Loss Firms } \\
\hline 1983-1985 & -0.006 & 0.640 & -0.646 & -0.005 & 0.199 & -0.204 & -0.001 & 0.441 & 0.039 \\
\hline $1986-1988$ & -0.004 & 0.830 & -0.834 & -0.010 & 0.231 & -0.241 & 0.007 & 0.599 & -0.043 \\
\hline $1989-1991$ & 0.002 & 0.387 & -0.385 & 0.119 & 0.070 & 0.050 & -0.117 & 0.318 & 0.158 \\
\hline Pooled & 0.002 & 0.514 & -0.512 & 0.028 & 0.093 & -0.066 & -0.026 & 0.421 & 0.097 \\
\hline \multirow{3}{*}{$\begin{array}{l}\text { Mean } \\
\text { Analysis }\end{array}$} & -0.002 & 0.561 & -0.563 & 0.049 & 0.312 & -0.263 & -0.051 & 0.249 & 0.123 \\
\hline & $(-0.108)$ & $(5.115)$ & $(-5.235)$ & $(0.996)$ & $(4.802)$ & $(-3.460)$ & $(-0.847)$ & (1.988) & $(1.444)$ \\
\hline & {$[0.916]$} & {$[0.001]$} & {$[0.001]$} & {$[0.348]$} & {$[0.001]$} & {$[0.009]$} & {$[0.422]$} & {$[0.082]$} & {$[0.187]$} \\
\hline
\end{tabular}

Notes: Coefficient estimates are based on ordinary least-squares estimation. The table reports the coefficient estimates, tstatistics, and p-values from cross-sectional and inter-temporal regressions. T-statistics are shown in parentheses and p-values are in brackets.

${ }^{a} I E$ is the measure of the incremental value relevance of earnings and is estimated by $R_{T}^{2}-I B V$.

${ }^{b} \mathrm{IBV}$ is the measure of the incremental value relevance of book value and is estimated by $\mathrm{R}_{\mathrm{T}}^{2}$ - IE.

${ }^{c} D_{I F F}$ common is the value relevance common to Canadian earnings and book value over that of U.S. earnings and book value and is calculated as Canadian ( $\mathrm{R}_{\mathrm{T}}^{2}$ - IE - IBV) - U.S. ( $\mathrm{R}_{\mathrm{T}}^{2}$ - IE - IBV).

Negative and positive earnings subgroups are from the matched sample. The matched sample consists of U.S. and Canadian firm-year observations matched by both industry and size.

In Table 5 we also report a cross-country comparison of (1) the level of incremental value relevance of accounting earnings, (2) the level of incremental value relevance of accounting book value and (3) the level of information that is jointly contained in earnings and book value of these two countries. We find that U.S. earnings clearly outperform Canadian earnings $\left(\mathrm{DIFF}_{\mathrm{IE}}=-0.123\right)$ to a significant degree $(\mathrm{p}=0.001)$. Canadian book value, 
even with its major role in market valuation relative to Canadian earnings, does not significantly outperform U.S. book value in incremental value relevance over and beyond earnings $\left(\mathrm{DIFF}_{\mathrm{IBV}}=0.009 ; \mathrm{p}=0.840\right)$. Additionally, U.S. and Canadian earnings and book value have equivalent levels of value relevance that is common to both earnings and book value $\left(\mathrm{DIFF}_{\text {common }}=0.027 ; \mathrm{p}=0.472\right)$. These results indicate that although the incremental value relevance of book value and the common value relevance of earnings and book value do not differ significantly across Canada and the U.S., U.S. earnings are significantly more value relevant than Canadian earnings.

Table 6 also reports the results of comparisons of the relative incremental value relevance of earnings and book value across the two countries for loss firms and profit firms. For profit firms, the incremental value relevance of U.S. earnings is greater than that of Canadian earnings $\left(\mathrm{DIFF}_{\mathrm{IE}}=-0.174 ; \mathrm{p}=0.001\right)$; however, there is no significant difference in the incremental value relevance of book value across these two countries when profits are reported $\left(\mathrm{DIFF}_{\mathrm{IBV}}=0.008 ; \mathrm{p}=0.796\right)$. For loss firms, Canadian and U.S. earnings are equivalent in their level of incremental value relevance (or lack of) $\left(\mathrm{DIFF}_{\mathrm{IE}}=-0.051 ; \mathrm{p}=0.422\right)$. Nevertheless, Canadian book value significantly outperforms its U.S. counterpart (i.e., has significantly higher incremental value relevance) when firms report losses $\left(\mathrm{DIFF}_{\mathrm{IBV}}=0.249 ; \mathrm{p}=0.082\right)$. There is no significant difference in the joint value relevance of earnings and book value for either the profit or the loss firm groups across the two countries $(\mathrm{p}=0.861$ for profit firms; $\mathrm{p}=$ 0.187 for loss firms). These results, together with results reported in Table 5, indicate that U.S. earnings are a stronger valuation proxy than Canadian earnings when firms report profits. However, Canadian book value is a much stronger valuation proxy than its U.S. counterpart when losses are reported.

Results from Table 5 and Table 6 support our second hypothesis that while the incremental value relevance of earnings for the U.S. firms is the highest when we only consider the profit firms compared to the full and the loss firm samples, the incremental value relevance of earnings for the Canadian firms does not improve with the removal of loss firms from the full sample. The incremental value relevance of book value, however, is the highest for both countries when loss firms are examined as a separate sample. Even though the inclusion of loss firms does not cause the comparison of IE ( $\mathrm{DIFF}_{\mathrm{IE}}$ ) between the two countries to be different from that of the profit-firm sample, i.e., the conclusion that U.S. earnings are more incrementally value relevant than their Canadian counterpart is unchanged; the result of the comparison of IB $\left(\mathrm{DIFF}_{\mathrm{IB}}\right)$ across the two countries is different for the loss-firm sample than the results of the comparison of IB for both the full sample and the profit-firm sample. Canadian book value has significantly higher incremental value relevance than U.S. book value for the loss-firm sample, which is contrary to the results for both the full sample and the profit-firm sample.

\section{CONCLUSIONS}

This study illustrates the potential impact of negative earnings (loss firms) on comparisons of the relative value relevance of earnings and book value across countries. We propose that in a cross-country comparative study, loss firms need to be separately examined and controlled. Depending on the specific relation between earnings and price for the loss firms of a particular country, the inclusion of loss firms in a cross-country comparative study in the full sample may produce biased results and lead to incorrect beliefs regarding the relative valuation implications of accounting fundamentals across countries. Using a matched sample of U.S. and Canadian firms, we investigate whether the cross-country rankings of (1) the combined value relevance of earnings and book value, (2) the relative value relevance of earnings and book value, and (3) the relative incremental value relevance of earnings (book value), is impacted by the presence of negative-earnings firm observations.

Our results show that removal of negative-earnings observations (1) change the total value relevance of earnings and book value combined, (2) change the relative value relevance of earnings and book value within each country, and (3) change the relative incremental value relevance of earnings (book value) across the two countries. These results not only indicate that separately controlling for loss firms in a cross-country comparative study is an important methodological issue; they also extend prior U.S. studies on the impact of negative earnings on equity valuation by providing additional evidence on Canadian firms.

Although only firms from two exchanges are used, this study should provide an example of the importance of negative earnings. Future research could examine this issue from the perspective of countries other than those included in this study. The impact of negative-earnings on different exchanges from the same country also could be 
investigated. Another interesting issue to address would be the change in the value relevance of earnings and book value for various countries over a time period longer than that investigated in this study and the impact of negative earnings on the value relevance of those items over time.

\section{AUTHOR INFORMATION}

Kathy H. Y. Hsu, Ph.D., associate professor of accounting at the University of Louisiana at Lafayette, has published manuscripts in journals such as Accounting Horizons, Decision Sciences, The Journal of International Accounting, Review of International Accounting and Finance, The Journal of Education for Business, and Managerial Finance. Dr. Hsu has had her research sponsored by AACSB International and is the recipient of several professional research awards.

Harlan Etheridge, Ph.D. is the Home Bank/BORSF Professor and an associate professor of accounting at the University of Louisiana at Lafayette who has published in journals such as Decision Sciences, The Journal of Accounting Literature, Advances in Accounting Information Systems, The International Journal of Intelligent Systems in Accounting, Finance and Management, Advances in International Accounting and The Journal of Education for Business. He also has published articles in practitioner journals such as The CPA Journal and CA Magazine and has presented papers at numerous regional, national and international conferences.

\section{REFERENCES}

1. Amir, E., and T. S. Harris, and E. K. Venuti. 1993. "A Comparison of the Value Relevance Of U.S. Versus Non-U.S. GAAP Accounting Measures Using Form 20-F Reconciliations”, Journal of Accounting Research, Vol. 31 (Supplement), pp. 230-275.

2. Barth, Mary E. and Greg Clinch. 1996. "International Accounting Differences And Their Relation to Share Prices: Evidence from U.K., Australian, and Canadian Firms”, Contemporary Accounting Research, 13 (1), (Spring): pp. 135-170.

3. Barth, M. E. 1991. "Relative Measurement Errors Among Alternative Pension Asset and Liability Measures", The Accounting Review, (1991): pp. 433-463

4. Barth, M. E. 1994. "Fair Value Accounting: Evidence From Investment Securities and the Market Valuation of Banks", The Accounting Review, (1994): pp.1-25

5. Barth, Mary E., William H. Beaver and Mark A. Wolfson. 1990. "Components of Earnings and the Structure of Bank Share Prices", Financial Analysts Journal, (May-June): pp.53-60

6. Berger, P., Ofek, E., Swary, I., 1996. "Investor Valuation of the Abandonment Option". Journal of Financial Economics, 42, pp. 257-287

7. Bandyopadhyay, Sati P., J. Douglas Hanna and Gordon Richardson. 1994. "Capital Market Effects of U.S.Canada GAAP Differences”, Journal of Accounting Research, (Autumn): pp. 262-277

8. Chan, Kam C., Benton E. Gup and Ming-Shiun Pan. 1997. "International Stock Market Efficiency and Integration: A Study of Eighteen Nations", Journal of Business Finance \& Accounting, 24(6): pp. 803-813.

9. Collins, Daniel W., Maydew L. Edward, Ira S. Weiss. 1997. "Changes in the Value Relevance of Earnings and Book Value Over the Past Forty Years", Journal of Accounting and Economics, 24: pp. 39-67

10. Collins, Daniel W., Morton Pincus and Hong Xie. 1999. "Equity Valuation and Negative Earnings: The Role of Book Value of Equity", The Accounting Review, (January): pp. 29-61.

11. Caylor, Marcus L, Thomas J Lopez, Lynn Rees. (2007). Is the value relevance of earnings conditional on the timing of earnings information? Journal of Accounting and Public Policy, 26(1), 62.

12. Easton, P., 1985. "Accounting Earnings and Security Valuation: Empirical Evidence of the Fundamental Links". Journal of Accounting Research, 23 (Suppl.), pp. 54-77.

13. Frankel, R. and C. Lee. 1996. "Accounting Diversity and International Valuation”, working paper.

14. Financial Accounting Standard Board. 1995. "Financial Reporting in North America: A Joint Study Undertaken by: Canadian institute of Chartered Accountants, Instituto Mexicano de Contadores Publicos, A.C., Financial Accounting Standards Board of the United States"

15. Hayn, C. 1995. "The Information Content of Losses", Journal of Accounting and Economics, 20: pp. 125153. 
16. Harris, T. S., M. Lang and H. P. Moller. 1994. "The Value Relevance of German Accounting Measures: An Empirical Analysis", Journal of Accounting Research, 32(2), (Autumn): pp. 187-209.

17. Kamarotou, H. and J. O'Hanlon. 1989. "Informational Efficiency in the UK, US, Canadian and Japanese Equity Markets: A Note”, Journal of Business Finance \& Accounting, 16(2): pp. 183-194.

18. Landsman, W. 1986. "An Empirical Investigation of Pension Fund Property in Accounting: A Review, Interpretation, and Extension”, The Accounting Review, (October): pp. 662-691

19. Nobe, C, "International Classification of Financial Reporting", Routledge, (1992)

20. Ohlson, J. 1995. "Earnings, Book Values, and Dividends in Security Valuation", Contemporary Accounting Research, 11, pp. 661-688.

21. Securities and Exchange Commission. 1993. "International Series Release No. 556: Amendments to the Multijurisdictional Disclosure System for Canadian Issuers.”, (July)

22. Theil, H. 1971. Principles of Econometrics. Wiley, New York, NY.

\section{NOTES}

